\title{
Studies of the coronary circulation in Chagas' heart disease
}

\author{
Division of Cardiology, Department of Internal Medicine, \\ Faculdade de Medicina de Ribeirão Preto, Universidade de São Paulo - São Paulo, Brazil
}

Pathogenesis of chronic Chagas' heart disease may include various disturbances in the coronary circulation, that could be responsible for the myocardial lesions seen in human hearts and in experimental models of the disease. In this paper we critically reviewed the anatomical and functional abnormalities described in chronic chagasic patients, pertaining to the so-called vascular pathogenetic theory of Chagas' disease. The epicardial coronary arteries are usually free of significant obstructive disease in nonselected groups of chagasic patients examined at autopsy or by coronary angiography. However, chagasic patients who were studied after an episode of acute myocardial infarction, show the same patterns of atherosclerotic coronary artery disease seen in

the general nonchagasic population. Studies of chagasic patients with angiographically normal coronary arteries, by several scintigraphy methods, revealed myocardial perfusion abnormalities which may be caused by the microcirculatory derangements described in animals experimentally infected with the T. cruzi. Since hypoperfusion has been detected in regions with normal or mildly impaired wall motion, it is likely that the microvascular disturbances precede and may be a causative mechanism for the subsequent myocardial damage. We speculate that hibernating ventricular areas may occur in chagasic patients, on the basis of the evidence gathered from these studies. Recent investigations of chronic patients with Chagas' disease and chest pain showed

attenuation of the vasomotor responses to physiological and pharmacological stimuli, in the epicardial coronary arteries.

UNITERMS: Chagas' disease. Coronary circulation. Acute myocardial infarction.

\section{INTRODUCTION}

$\mathrm{D}$ erangements of the coronary circulation were postulated to occur in chagasic patients $(45,47)$ soon after the nosologic discovery of the disease by Carlos Chagas in the beginning of this century. After

\author{
Address for correspondence: \\ José Antonio Marin-Neto \\ Divisão de Cardiologia, Departamento de Clínica Médica \\ Faculdade de Medicina de Ribeirão Preto \\ Universidade de São Paulo \\ Ribeirão Preto - SP - Brasil - CEP 14049-900
}

those early studies much knowledge was achieved on the basis of experimental evidence, thus originating the socalled vascular theory of Chagas' disease pathogenesis. Several independent studies in experimental models of $T$. cruzi infection showed evidence of coronary microcirculatory disturbances that were the object of previous review (35). These abnormalities are believed to compound with immunopathogenetic mechanisms, and trigger Chagas' myocarditis (36).

The purpose of this paper is critically review the evidence of functional and anatomical derangements of the coronary circulation in human Chagas' disease, as derived from studies from our and others' laboratories. 


\section{IN VIVO AND POSTMORTEM STUDIES OF THE EPICARDIAL CORONARY CIRCULATION IN CHRONIC CHAGAS' DISEASE PATIENTS.}

Studies of the epicardial coronary circulation in chronic chagasic patients have been prompted by clinical manifestations of Chagas' disease. Thus, a substantial proportion of chagasic patients complains of chest pain, frequently with angina-like characteristics that require careful consideration of coronary disease as the causative mechanism (22,41). Many of these patients have concomitant electrocardiographic abnormalities, compatible with electrically inactive areas suggestive of regional fibrosis; it is also very common to have conduction disturbances with profound ST-T changes that limit one's ability to rule out ischemia either at rest or during stress $(1,9,13,22)$. Finally, similarly to coronary heart disease, regional ventricular dyssynergy is common in chagasic patients, even in very dilated hearts $(4,14,23,24)$. This is a distinctive feature of Chagas' heart disease, useful to differentiate it from primary dilated cardiomyopathy, but difficult to distinguish from the effects of coronary heart disease.

Necropsy observations in chronic chagasic patients usually show mild coronary atherosclerotic lesions, mainly in older patients (22). However, the atherosclerotic involvement is rarely severe enough to explain the extensive myocardial impairment $(43,44)$. These observations were corroborated by several independent studies using coronary angiography in Chagas' heart patients $(4,9,14,23)$.

One investigation in autopsied chagasic patients correlated the prevalence of the characteristic apical aneurysm with the heart weight, and the relative myocardial distribution of both coronary arteries (27). The findings of this investigation supported the conclusion that unfavorable perfusion conditions prevailed in the apical region of the heart of chagasic patients, thus providing an ischemic basis for the appearance of the apical aneurysm.

Further evidence was obtained from human necropsy studies, showing structural vascular disarray in the left ventricle of chagasic patients $(10,15,44)$. These alterations are likely to be caused by inflammatory vascular changes, leading to reparative fibrosis, and correspond to the lesions described in animals experimentally infected with the $T$. cruzi $(21,32)$. In special, the vasculitis detected in the apical region was implicated in the genesis of the apical aneurysm, preceding the appearance of this lesion in $30 \%$ of the chagasic hearts (10). However, coronary vasculitis was not found by other investigators, in necropsy studies and in animal models of the T. cruzi infection $(7,11)$. In the latter studies, essentially all the morphological and microscopic lesions usually seen in human Chagas' disease were reproduced in the experimental model, including the apical aneurysm $(11,38)$. These studies also described two additional pathological aspects: a) occlusive pratelet thrombosis of the epicardial and intramural coronary microvasculature (38); b) histochemical evidence of focal myocardial hypoxic lesions (37).

Another postmortem study showed increased volumetric capacity of the coronary circulation (vessel diameter $>40 \mu$ ), in chagasic patients, as compared with normal controls and hypertrophic patients (33). In this investigation no better perfusion conditions were implied as associated with the epicardial vasodilatation thus suggested. The coronary vasodilatation was postulated to depend on stimulation of the alpha adrenergic receptors, that would be unopposed by parasympathetic denervation. Therefore, the results of that investigation were interpreted as supporting the neurogenic theory of the Chagas' disease cardiomyopathy (33). The underlying pathogenetic mechanism would be the impairment of the autonomic control of the coronary circulation. However, the real role of the alpha adrenergic receptors in the control of the coronary epicardial circulation remains to be defined. Moreover, it was disturbing to see that immediately preceding that report (33), clear evidence of cardiomyopathy and coronary vasoconstriction caused by infusion of cathecolamines was published (42). Of significance, such deleterious effects were blocked by specific alpha receptor antagonists (42).

\section{ANATOMICAL STUDIES OF THE CORONARY CIRCULATION IN CHAGASIC PATIENTS AFTER ACUTE MYOCARDIAL INFARCTION}

There have been sparse reports of chagasic patients who had an episode of acute myocardial infarction, with pervious coronary arteries revealed by angiography or autopsy studies $(29,46)$. Among the various pathophysiological hypotheses suggested in those reports to explain the fact, most favored coronary embolism with spontaneous recanalization or coronary spasm, as the likely mechanisms. This is similar to the predominant thoughts about myocardial infarction with angiographically normal coronary arteries in nonchagasic populations. 
However, it is noteworthy that in the last decades an intense process of progressive urbanization occurred regarding the previously country-based chagasic population. As a consequence, profound lifestyle modifications led to exposure of chagasic patients to the same risk factors for atherosclerosis that are operative in the nonchagasic population. Therefore, it became plausible to assume that coronary atherosclerotic disease might not be infrequently found in concomitance with Chagas' heart disease. This concept is supported by the indirect evidence that of 136 chagasic patients who were submitted to cardiac catheterization because of an associated cardiopathy, hemodynamically significant coronary obstructions were found in 51 patients (37\%) (12).

A retrospective study in our institution (5) directly tested the hypothesis that the association of myocardial infarction and normal coronary arteries would be more frequent in chagasic as compared to nonchagasic patients. The clinical files, and necropsy reports of 395 consecutive patients presenting with acute myocardial infarction from 1981 to 1988 were analyzed. In all cases the diagnosis of infarction was confirmed by electrocardiographic and/or enzymatic criteria. Coronary angiographic findings were analyzed by computer assisted detection of vascular edges, and subsequent quantitation of the stenoses. Of the 395 patients with myocardial infarction studied, $39(9.9 \%)$ had also a diagnosis of Chagas' disease confirmed by serological tests. In 26 of them, the coronary anatomy was determined by angiography and/or autopsy. In the nonchagasic population with acute myocardial infarction the coronary anatomy was known in 219 patients. The frequency of normal coronary arteries was statistically comparable for both groups: 2 in $26(7.7 \%)$ and 17 in 219 $(7.8 \%)$ respectively for the chagasic and nonchagasic groups. (Table 1). The distribution of hemodynamically significant stenoses ( $>50 \%$ of luminal diameter narrowing) in the chagasic population showed univascular involvement in $38 \%$, and multivascular in $53 \%$ of patients. The myocardial area of infarct corresponded to the lesion in the culprit coronary artery in all cases, and no anthropometric, clinical, risk factor distribution or inhospital evolution characteristics were found to discriminate between the two groups of patients. The prevalence of coronary arteries with no detectable lesions found in this study, for both the chagasic and nonchagasic patients is similar to that reported for non selected populations in the literature, of $6 \%$ (31).

These findings were corroborated by those reported from another institution (34), with 13 consecutive chagasic patients catheterized during the acute phase of an acute myocardial infarction. Only 1 patient $(8 \%)$ had angiographically normal coronary arteries, while $54 \%$ of the cases presented multivascular lesions.

These observations are consistent with the concept that, similarly to what is characteristic for nonchagasic patients, acute myocardial infarction is caused by atherosclerotic coronary involvement in chronic chagasic individuals.

Table 1

Results of quantitative coronary angiography in chagasic and nonchagasic patients with acute myocardial infarction from 1981 to 1988 at the Medical School of Ribeirão Preto, USP

Chagasic Nonchagasic

\begin{tabular}{lcc}
$\begin{array}{l}\text { Total of patients with AMI } \\
\begin{array}{l}\text { Number with coronary } \\
\text { angiography }\end{array}\end{array}$ & 39 & 56 \\
$\begin{array}{l}\text { Normal coronaries } \\
\text { Normal }\end{array}$ & 26 & 219 \\
\hline
\end{tabular}

* $\mathrm{AMI}=$ acute myocardial infarction

\section{FUNCTIONAL STUDIES OF THE CORONARY CIRCULATION IN PATIENTS WITH CHRONIC CHAGAS' DISEASE}

Under this heading a heterogeneous group of investigations is comprised, aiming at the detection of objective evidence of myocardial ischemia, as well as of regional ventricular dysfunction as a consequence of ischemia, in Chagas' heart patients. Also included in this topic are the more recent studies of the coronary reactivity to physiological and pharmacological stimuli.

\section{1 - Studies of the regional myocardial perfusion.}

The pioneer investigations of E. Kuschnir and coworkers $(16,19)$, using 86 -rubidium, showed absolute reduction of regional effective myocardial flow in Chagas' heart patients. The flow reduction, of magnitude comparable to that exhibited by nonchagasic patients with proven coronary obstruction, was observed both at baseline (19), and during effort (although less markedly) (16). 
The perfusion disturbances were also detected using 201-thallium at rest (39), and during exercise (28), in chronic chagasic patients. In the latter investigation, fixed perfusion defects detected in the apical region occurred in $37 \%$ of the patients with the cardiac form and in $25 \%$ of the patients in the indeterminate phase of Chagas' disease. The fixed perfusion defects were interpreted as probably corresponding to localized fibrosis in the typical apical region, commonly leading to aneurysms in Chagas' disease patients (28).

The occurrence of regional perfusion defects in chagasic patients at several stages of the disease was confirmed by other independent investigations, using 201thallium (13,23), or $99 \mathrm{~m}$-technetium labelled sextamibi (6). In addition to the fixed defects already mentioned, the studies with 201-thallium showed perfusion disturbances occurring only during stress (reversible) or as reverse redistribution (paradox defects) (23). The reversible perfusion abnormalities suggested that stressinduced ischemia could occur in Chagas' disease patients. The paradox defects, detected in $61 \%$ of the patients, were compatible with disturbances at the sarcolemmal level, possibly due to impairment of capacity to retain the tracer during the rest phase of the scintigraphic study (23).

In a recent study we used an specific marker of regional myocardial flow, whose distribution is independent of the metabolic properties of the sarcolemma (25). Human albumin microspheres labelled with $99 \mathrm{~m}$-technetium were injected in the left ventricle of 18 chagasic patients submitted to coronary angiography because of recurrent severe chest pain. The scintigraphic distribution of the microspheres was assessed in the three planar standard views, allowing the analysis of 7 segments per patient for both perfusion and regional wall motion (Table 2).

All patients had angiographically normal coronary arteries and the mean left ventricle ejection fraction was $52 \pm 12$. At least 1 perfusion defect was detected in all patients. Ten of them had $>3$ abnormal segments (Fig. 1). The number of regional perfusion defects per segment, and the respective wall motion pattern are found in Table 2.

The results of this investigation lead to the conclusion that true perfusion defects do occur in chronic chagasic patients. The defects associated with akinesis or dyskinesia are predominant in the apical region, and may correspond to local fibrosis. On the other hand, the perfusion defects found in zones with preserved wall motion or with mild hypokinesis, are likely to be caused by microvascular disturbances, as the epicardial coronary circulation is essentially normal in these chagasic patients (25).
Table 2

Number of perfusional defects per segment, correlated to the regional wall motion pattern, in chagasic patients injected with 99 m-technetium microspheres.

Al Ap I Sep PI A $P$

Normal/

\begin{tabular}{llllllll}
$\begin{array}{l}\text { Hypokinesis } \\
\text { Akinesis/ }\end{array}$ & 6 & 1 & 1 & 5 & 6 & 3 & 8 \\
Dyskinesia & 0 & 15 & 1 & 1 & 2 & 0 & 0 \\
\hline
\end{tabular}

Segment analysis: anterolateral (Al), apical (Ap), inferior (I), septal (Sep), posterolateral (PI), anterior (A); posterior $(\mathrm{P})$.

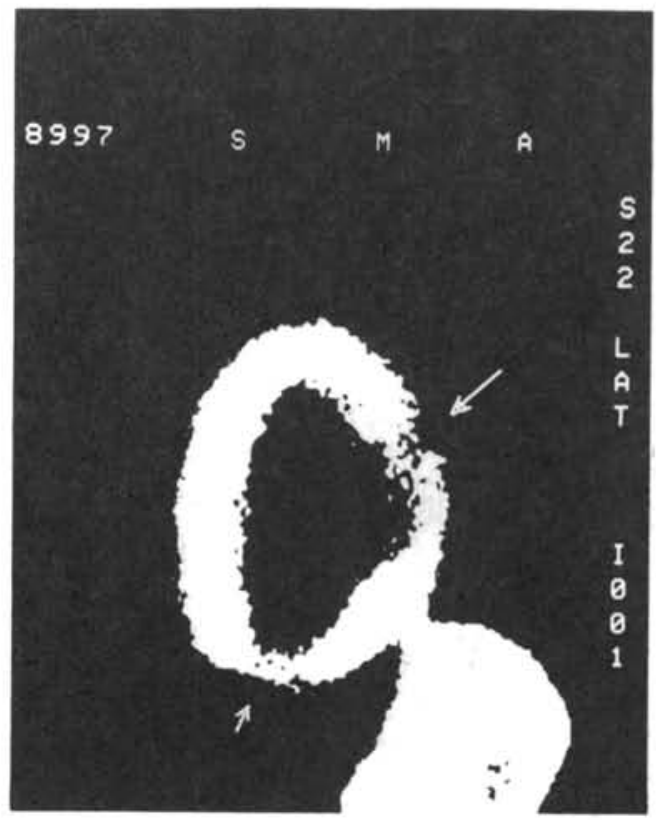

Figure 1 - Planar myocardial scintigraphy following left ventricular injection of $99 \mathrm{~m}$-technetium labelled microspheres, in a chronic chagasic patient with marked chamber dilatation. Hypoperfusion is seen in the lateral projection, in the apical (short arrow) and high posterior (long arrow) regions.

\section{2 - Studies of the relation between regional perfusion and contraction in Chagas' disease.}

The highly complex interdependency between regional perfusion and wall motion that usually prevails in the normal myocardium may theoretically be disrupted in Chagas'disease by several mechanisms. For instance, it seems plausible to speculate that chronic regional hypoperfusion, as demonstrated in the investigations 
mentioned above, might lead to localized, potentially reversible dyssynergy. This hypothesis is compatible with the results of studies showing improvement of left ventricular function in chronic chagasic patients, who received acute or chronic administration of dipyridamole $(18,20)$ and isosorbide dinitrate $(17,26)$. It is possible that such amelioration of the ventricular performance shown in chagasic patients could merely reflect more favorable preload and afterload conditions during the effect of these vasodilator. However, the observation of disappearance of 201-thallium perfusion defects after chronic treatment of chagasic patients with dipyridamole, supports the concept that abolishing regional underperfusion may contribute to the reversal of wall motion abnormalities documented after administration of vasodilator (39).

We consider that these investigations should be validated by specific studies aiming at the confirmation of the existence of chronically underperfused, hypocontractile myocardium in Chagas' heart disease. This would be similar to the hibernating myocardium seen in chronic coronary artery disease, and might have relevant clinical implications for the management of chagasic patients.

This hypothesis, coherent with the experimental observations that underlie the vascular pathogenetic theory of Chagas' disease $(8,11,38)$, is also compatible with the results of preliminary studies in animal models of the disease (30), and in humans (39), showing promising beneficial effects of therapeutic interventions with vasodilators.

\section{3 - Studies of coronary reactivity to physiological and pharmacological stimuli in chronic chagasic patients.}

Vasospasm has been implied as the mechanism underlying acute ischemic syndromes in Chagas' heart patients (46). Since prolonged hyperventilation has been demonstrated to induce coronary spasm (that is reversible with nitrates) in patients with Prinzmetal angina (3), we conducted a study in chagasic patients with angina-like symptoms severe enough to warrant coronary angiography, to test directly the hypothesis that such patients are prone to have coronary vasospasm responsible for their symptoms (40). Vasomotor responses to hyperventilation and sublingual isosorbide dinitrate administration were studied in the epicardial coronary arteries of 14 chagasic patients (mean age $=57 \pm 11$ years) e 11 control subjects also presenting with angina (mean age $=45 \pm 15$ years). All patients were studied at baseline and 5, 10, and 15 minutes after hyperventilation for 5 minutes, and again following the sublingual administration of $5 \mathrm{mg}$ of dinitrate isosorbide. Quantitative angiography was performed in proximal and distal segments of the left anterior descending artery.

All 25 patients had normal coronary arteries or nonsignificant lesions $(<50 \%$ reduction of luminal diameter). No episode of focal or diffuse coronary spasm could be detected in any of the patients, who also had no ischemic electrocardiographic changes following hyperventilation. Minor comparable changes were observed in both groups, for heart rate and blood pressure, after hyperventilation and nitrate administration. The $\mathrm{P}_{\mathrm{a}} \mathrm{CO}_{2}$ decreased to 21.9 and $19.8 \mathrm{mmhg}$, following hyperventilation, respectively for the chagasic and control groups. The absolute values for the luminal diameters, in $\mathrm{mm}$, are presented in Table 3. Baseline diameters were significantly larger in the chagasic group. In contrast, diameter changes evoked by hyperventilation and nitrate administration were significantly more pronounced in the control group, for both the proximal and the distal segments of the left anterior descending artery.

Table 3

Absolute luminal diameter $(\mathrm{mm})$ of proximal (P-LAD) and distal (D-LAD) segments of the left anterior descending coronary artery in chronic chagasic cardiomyopathy (CCC) patients and in normal controls $(\mathrm{N})$.

\begin{tabular}{lcccc} 
& \multicolumn{2}{c}{ CCC } & \multicolumn{2}{c}{$N$} \\
& P-LAD & D-LAD & P-LAD & D-LAD \\
\hline B & $2.72 \pm 0.6$ & $1.40 \pm 0.2$ & $2.56 \pm 0.4$ & $1.44 \pm 0.3$ \\
H-5 min & $2.65 \pm 0.5$ & $1.34 \pm 0.2$ & $2.47 \pm 0.4$ & $1.41 \pm 0.3$ \\
H-10min & $2.61 \pm 0.5$ & $1.40 \pm 0.2$ & $2.42 \pm 0.3^{*}$ & $1.25 \pm 0.2^{*}$ \\
H-15min & $2.69 \pm 0.6$ & $1.34 \pm 0.1$ & $2.53 \pm 0.4$ & $1.29 \pm 0.2$ \\
DNIS & $2.86 \pm 0.6$ & $1.47 \pm 0.2$ & $2.98 \pm 0.6^{\star \star} 1.74 \pm 0.4^{* \star}$ \\
\hline
\end{tabular}

$\mathrm{B}=$ baseline; $\mathrm{H}-5,10 \mathrm{~min}, 15 \mathrm{~min}=\operatorname{after} 5,10$ and 15 minutes of hyperventilation; DNIS $=$ after administration of $5 \mathrm{mg}$ of dinitrate isosorbide by sublingual route. ${ }^{*} p<$ $0.05-{ }^{* \star} p<0.01$, relative to the respective baseline values.

Thus, coronary spasm does not seem to play a significant role in the genesis of angina-like symptoms in Chagas' heart patients. Furthermore, vasomotor responses of the epicardial coronary arteries to vasoconstrictor and vasodilator stimuli are blunted in chronic chagasic patients. 
The findings of this investigation, showing relative baseline vasodilation in the coronary epicardial circulation, seem to represent the counterpart, in vivo, of the increased volumetric coronary capacity demonstrated in necropsy studies of chronic chagasic patients (11). The mechanisms responsible for these findings are not clear. The autonomic dysfunction, postulated following the necropsy studies, remains a possible explanation, requiring a direct investigation. Only one study addressing the issues of perfusion defects and autonomic dysfunction, in the same group of chagasic patients, has been reported, no correlation between both types of abnormalities being found (23). However, it must be pointed out that, in this study, only the autonomic control of the sinus node was directly assessed, and no attempt to test the regulation of the coronary circulation was carried out.

\section{Resumo}

Anormalidades anatômicas e funcionais da circulação coronária têm sido descritas e englobadas na teoria vascular da patogênese da cardiopatia chagásica crônica. Neste artigo foram criticamente revistos resultados de estudos em humanos e modelos experimentais da infecçāo com o $T$. cruzi, sobre aspectos anatômicos e funcionais da circulação coronária, a nível epicárdico e microvascular. Por evidências necroscópicas, e cinecoronariográficas, as artérias epicárdicas não exibem, em geral, lesōes obstrutivas consideradas capazes de induzir isquemia miocárdica. Constituem exceçāo aqueles pacientes chagásicos estudados após episódio de infarto agudo do miocárdio, que apresentam freqūência de obstruçōes coronarianas superponível à encontrada na população nāo-chagásica, com infarto agudo do miocárdio. Distúrbios perfusionais, compatíveis com as alteraçōes microvasculares experimentalmente documentadas, são observados em pacientes chagásicos crônicos com coronárias angiograficamente normais. Essas alteraçōes podem ter relaçāo causal com a disfunção contrátil regional detectada em regiōes com hipoperfusāo crônica, sugerindo a ocorrência de possiveis áreas de "hibernação" miocárdica, análoga à que se verifica na cardiopatia isquêmica ateroesclerótica. Investigaçōes recentes em cardiopatas chagásicas com precordialgia sugerem anormalidades no controle vasomotor coronariano, havendo atenuação das respostas arteriais epicárdicas aos estímulos 


\section{REFERENCES}

1. AMORIM, D.S.; MANÇO, J.C.; GALLO JR., L. \& MARINNETO, J.A. - Clínica: forma crônica cardíaca. In: Brener Z, Andrade Z, eds. Trypanosoma cruzi e doença de Chagas. Rio de Janeiro, Guanabara Koogan, 1979.

2. ANDRADE, Z.A. \& ANDRADE, S.G. - A patogenia da miocardite crônica chagásica (a importância das lesões isquêmicas). Arq Bras Med 45: 279-290, 1955.

3. ARDISSINO, D.; DE SERVI, S.; FALCONE, C. et al. - Role of hypocapnic alkalosis in hyperventilation-induced coronary artery spasm in variant angina. Am J Cardiol 59: 708-710, 1987.

4. ARREAZA, N.; PUIGBÓ, J.J.; ACQUATELLA, H. et al. Radionuclide evaluation of left-ventricular function in chronic Chagas' cardiomyopathy. J Nucl Med 24: 563-567, 1983 .

5. AYRES-NETO, E.M.; MACIEL, B.C.; MARIN-NETO, J.A. \& AMORIM, D.S. - O infarto agudo do miocárdio na cardiopatia chagásica crônica é devido a lesões coronarianas comuns na doença isquêmica aterosclerótica. (Abstract). Rev Soc Cardiol do Estado de São Paulo 4 (3-Supl.B): 44, 1994.

6. CASTRO, R.; KUSCHNIR, E. \& SGAMMINI, H. Evaluacion de la performance cardiaca y perfusion miocardica con radiotrazadores en la cardiopatia chagasica cronica. Rev Fed Arg Cardiol 17: 226-231, 1988.

7. CHAPADEIRO, E. - Sobre as lesões vasculares na cardiopatia chagásica crônica. Hospital (Rio de Janeiro) 67: 1027, 1965.

8. FACTOR, S.M.; SHO, S.; WITTNER, M. \& TANOWITZ, H. - Abnormalities of the coronary microcirculation in acute murine Chagas' disease. Am J Trop Med Hyg 34: 246-253, 1985.

9. FEIT, A.; EL-SHERIF, N. \& KOROSTOFF, S. - Chagas' disease masquerading as coronary artery disease. Arch Intern Med 143: 144-145, 1983.

10. FERREIRA, C.S.; LOPES, E.R.; CHAPADEIRO, E.; ALMEIDA, H.O. \& SOUZA, W.F. - Coronariografia e ventriculografia post mortem na cardite chagásica crônica. Correlação anátomo-radiológica. In: Décourt, L.V. \& Campos, O.M. Modernos Conhecimentos sobre Doença de Chagas. Belo Horizonte, Universidade Federal de Minas Gerais; Academia Mineira de Medicina, 1981. p. 29-38.

11. FIGUEIREDO, F.; MARIN-NETO, J.A. \& ROSSI, M.A. The evolution of experimental Trypanosoma cruzi cardiomyopathy in rabbits: further parasitological, morphological and functional studies. Int J Cardiol 10: 277 $290,1986$.
12. GARZON, S.A.C. - Doença de Chagas associada a outras cardiopatias. In: Cançado, J.R.; Chuster, M. eds. Cardiopatia chagásica. Belo Horizonte, MG. Fundação Carlos Chagas, 1985. p. 255-265.

13. HAGAR, J.M. \& RAHIMTOOLA, S.H. - Chagas' heart disease in the United States. N Engl J Med 325(II): 763 768, 1991.

14. HAMMERMEISTER, K.E.; CAEIRO, T.; CRESPO, E.; PALMERO, H. \& GIBSON, D.G. - Left ventricular wall motion in patients with Chagas' disease. Br Heart J 51: 7076,1984 .

15. JÖRG, M.E. - Tripanosomiasis cruzi; anarquia angiotopográfica por descapilarización mesenquimorreactiva, cofactor patogênico de la miocardiopatia crónica. Pren Med Argent 61: 94-106, 1974.

16. KUSCHNIR, E.; EPELMAN, M.; KUSTICH, F.; SANTAMARINA, N. \& PODIO, R.B. - Valoración del fluxo miocárdico con $\mathrm{Rb} 86$, en pacientes con cardiopatia chagásica, con insuficiencia coronaria y en controles normales. Parte 2: respuesta al ejercicio y a la cardiotonificación aguda. Arq Bras Cardiol 27: 721-732, 1974.

17. KUSCHNIR, E.; KUSTICH, F.; EPELMAN, M.N. \& PODIO, R.B. - Estudios del flujo miocárdico en pacientes com insuficiencia coronaria y en pacientes con cardiopatía chagásica crónica. Respuesta a la administración de dinitrato de isosorbide y dipiridamol. Pren Med Arg 60: 637-650, 1983.

18. KUSCHNIR, E.; KUSTICH, F.; EPELMAN, M. \& PODIO, R.B. - Efectos del dipiridamol sobre la funcion ventricular en pacientes con miocardiopatia chagásica crónica. Estudios con camara gamma computada. Rev Fed Arg Cardiol 10: 3-12, 1981 .

19. KUSCHNIR, E.; KUSTICH, F.; EPELMAN, M.; SANTAMARINA, N. \& PODIO, R.B. - Valoración del flujo miocárdico con $\mathrm{Rb} 86$, en pacientes con cardiopatia chagásica, con insuficiencia coronaria y en controles normales. Parte 1: estudios basales. Arq Bras Cardiol 27: 187-196, 1974.

20. KUSCHNIR, E.; SGAMMINI, H.; CASTRO, R.; EVEQUOZ, C. \& LEDESMA, R. - Miocardiopatia chagásica crónica: effectos del dipiridamol sobre la dinámica ventricular. Arq Bras Cardiol 41: 373-378, 1983.

21. LAGE, S.G.; MANSUR, A.P.; RAMIREZ, J.A.F.; LUZ, P.; BELLOTTI, G. \& PILEGGI, E. - Acute myocardial infarction in chronic Chagas, cardiomyopathy: report of two cases with no obstructive coronary artery lesions. Rev Inst Med Trop S Paulo 28: 131-137, 1986. 
22. LARANJA, F.S.; DIAS, E.; NOBREGA, G. \& MIRANDA, A. - Chagas' disease. A clinical, epidemiologic, and pathologic study. Circulation 14: 1035-1060, 1956.

23. MARIN-NETO, J.A.; MARZULLO, P.; MARCASSA, C. et al. - Myocardial perfusion abnormalities in chronic Chagas' disease detected by thallium-201 scintigraphy. Am J Cardiol 69: 780-784, 1992.

24. MARIN-NETO, J.A.; MARZULLO, P.; SOUSA, A.C.S. et al. - Radionuclide angiographic evidence for early predominant right ventricular involvement in patients with Chagas' disease. Can J Cardiol 4: 231-236, 1988.

25. MARIN-NETO, J.A.; MARZULLO, P.; PINTYA, A.O.; MACIEL, B.C.; GALLO JR., L. \& L'ABBATE, A. Myocardial perfusion disturbances detected by ${ }^{99 m}-\mathrm{Tc}$ microspheres in Chagas' patients with angiographically normal coronary arteries. (Abstract). Eur Heart J 362, 1994.

26. MARIN-NETO, J.A.; SOUSA, A.C.S.; MACIEL, B.C.; GALLO JR., L. \& IAZIGI, N. - Avaliação angiocardiográfica nuclear do efeito do dinitrato de isosorbitol em pacientes chagásicos. Arq Bras Cardiol 51(5): 367-371, 1988.

27. MELLO DE OLIVEIRA, J.A. - Contribuição ao estudo da patogenia do "aneurisma de ponta" na cardiopatia chagásica. 1967 [Tese - Ribeirão Preto, Universidade de São Paulo].

28. MENEGHELO, R.S.; THOM, A.F. \& MARTINS, L.R.F. Aspectos da cintilografia miocárdica. In: Cançado, J.R. \& Chuster, M. eds. Cardiopatia chagásica. Belo Horizonte, MG. Fundação Carlos Chagas, 1985. p. 184-187.

29. MORAIS, C.F. \& HIGUCHI, M.L. - Chagas' heart disease and myocardial infarct incidence and report of four necropsy cases. Ann Trop Med Parasit 83(3): 207-214, 1989.

30. MORRIS, S.A.; WEISS, L.M.; FACTOR, S.; BILEZIKIAN, J.P.; TANOWITZ, H. \& WITTNER, M. - Verapamil ameliorates clinical, pathologic and biochemical manifestations of experimental chagasic cardiomyopathy in mice. J Am Coll Cardiol 14: 782-789, 1989.

31. Myocardial infarction and with angiographically normal coronary vessels. Heart Disease. A textbook of cardiovascular medicine. 4th edition. W.B. Saunders, 1992. p. 1208 .

32. OKUMURA, M.; BRITO, T.; PEREIRA-DA-SILVA, L.H.; CARVALHO-DA-SILVA, A. \& CORREA-NETO, A. - The pathology of experimental Chagas, disease in mice. I. Digestive tract changes with special reference to necrotizing arteritis. Rev Inst Med Trop São Paulo 2: 17-28, 1960.

33. OLIVEIRA, J.S.M.; MONTEIRO DOS SANTOS, J.C. \& MUCCILLO, A.L. - Increased capacity of the coronary arteries in chronic Chagas, heart disease: further support for the neurogenic pathogenesis concept. Am Heart J 109(2): 304-308, 1985.

34. RAMOS, R.F.; TAKIMURA, C.K.; LASSO, J.R.M. et al. É a embolia coronariana a responsável pelo infarto agudo em chagásicos? Arq Bras Cardiol 61 (Suppl II): 125, 1993.

35. ROSSI, M.A. - Microvascular changes as a cause of chronic cardiomyopathy in Chagas' disease. Am Heart J 82: 19001909, 1990.

36. ROSSI, M.A. - Patogênese da miocardite chagásica crônica. Rev Soc Cardiol Estado de São Paulo 4: 85-91, 1994.

37. ROSSI, M.A. \& CAROBREZ, S.G. - Experimental Trypanosoma cruzi cardiomyopathy in BALB/c mice: histochemical evidence of hypoxic changes in the myocardium. Br J Exp Pathol 66: 155-160, 1985.

38. ROSSI, M.A.; GONÇALVES, S. \& RIBEIRO-DOSSANTOS, R. - Experimental Trypanosoma cruzi cardiomyopathy in BALB/c mice: the potential role of intravascular platelet aggregation in its genesis. Am J Pathol 114: 209-216, 1984.

39. ROTONDARO, D.; CASTELLETTI, L.J.; RIOS, V. et al. Cambios en las imágenes de perfusión miocárdica con talio 201 en pacientes com miocardiopatía chagásica crónica, despúes del tratamiento con dipiridamol. Arq Bras Cardiol 47: 129-136, 1979.

40. SIMÕES, M.V.; AYRES-NETO, E.M.; ATTAB-SANTOS, J.L.; MACIEL, B.C. \& MARIN-NETO, J.A. - Cardiopatas chagásicos crônicos têm respostas atenuadas a estímulos vasomotores na circulação coronariana sub-epicárdica. (Abstract). Rev Soc Cardiol do Estado de São Paulo 4 (3Supl.B): 20, 1994.

41. SIMÕES, M.V.; AYRES, E.M.; SANTOS, J.L.A. et al. Deteç̧ão de isquemia miocárdica em chagásicos crônicos com precordialgia atípica pelos testes de esforço e Holter. Arq Bras Cardiol 60(5): 315-319, 1993.

42. SIMONS, M. \& DOWNING, S.E. - Coronary vasoconstriction and catecholamine cardiomyopathy. Am Heart J 109(2): 297-308, 1985.

43. SUÁREZ, J.A. - Coronariografia post mortem en miocardiopatia chagásica. Gac Med Caracas 75(1-6): 57 93, 1967.

44. TORRES, C.M. - Aterosclerose das finas ramificações arteriais do miocárdio (coronarite chagásica) e miocitólise focal do miocárdio na cardiopatia chagásica crônica. Hospital 54: 597-610, 1958.

45. TORRES, C.M. - Estudo do miocárdio na moléstia de Chagas (forma aguda). Mem Inst Oswaldo Cruz 9: 113, 1917. 
46. VIANNA, L.G.; CAMPOS, G.P. \& MAGALHÃES, A.V. Infarto do miocárdio sem obstrução coronariana associado a cardiopatia chagásica crônica. Arq Bras Cardiol 33(1): 4147, 1979.

47. VIANNA, G. - Contribuição para o estudo da anatomia patológica de moléstia de Chagas. Mem Inst Oswaldo Cruz 3: $276,1911$.
48. WAINRACH, S.; FABIUS, A.; CIRILE, J.P. \& ACOSTAFERREIRA, W. - Infarto do miocárdio en la cardiopatia chagásica. Tórax 4: 255, 1955. 